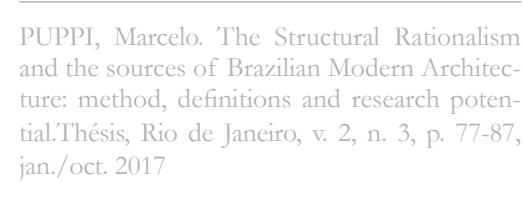

submission date: $11 / 10 / 2016$ acceptance date: $25 / 04 / 2017$

\title{
The Structural Rationalism and the sources of Brazilian Modern Architecture: method, definitions and research potential
} Marcelo Puppi

Marcelo Puppi é Doutor em História da Arte pela Universidade de Paris 1 Panthéon-Sorbonne; professor na Universidade Estadual de Londrina; marcelopuppi@uol.com.br

\begin{abstract}
The research has two main objectives: first, expand the knowledge of the sources of the theory and practice of Brazilian modern architecture and, second, contribute to the consolidation of the cultural history of architecture in Brazil. Studying the structural rationalism as source of the Brazilian modern architecture does not only mean to deepen the knowledge already in progress on the latter, but also to apply the cultural history method to the stu$d y$ of the history of architecture in Brazil. For the recent research about the structural rationalism benefited from the cultural history method and is part of the new architectural history of the XIX century, elaborated since 1990, approximately. In this context, the very definition of structural rationalism is amplified and deepened. Instead of simply meaning a relation of cause and effect between structure and architecture in which the structure is one of the architecture's purposes, the structural rationalism is now understood as part of the new dynamic and organic conception of the architecture that emerges in the XIX century, for which, particularly, the structure is the means capable to fully generate the organic unity of the form. In this perspective, demonstrate that the structural rationalism is one of the sources, and more precisely one of the greatest sources of Brazilian modern architecture, not only permit to deepen the knowledge of the theoretical assumptions, but also the formal qualities of this architecture. As well as, consequently, the more general matters as the composition method and the architecture's cultural role that are relevant today and ever to the theory and the practice of the architecture.
\end{abstract}

Keywords: theoretical sources, brazilian modern architecture, structural rationalism, cultural history of architecture.

\section{Resumo}

A pesquisa tem dois objetivos principais: primeiro, ampliar o conhecimento das fontes da teoria e da prática da arquitetura moderna brasileira e, segundo, contribuir para a consolidação da história cultural da arquitetura no Brasil. Estudar o racionalismo estrutural como fonte da arquitetura moderna brasileira não significa apenas aprofundar o conhecimento já em curso sobre esta última, mas também aplicar o método da história cultural ao estudo da história da arquitetura no Brasil. Pois a pesquisa recente sobre o racionalismo estrutural beneficiou-se do método da história cultural e é parte da nova história da arquitetura do século XIX elaborada a partir de 1990 aproximadamente. Nesse contexto, a própria definição de racionalismo estrutural é ampliada e aprofundada. Ao invés de significar simplesmente uma relação de causa e efeito entre estrutura e arquitetura na qual a estrutura é um dos fins da arquitetura, o racionalismo estrutural passou a ser compreendido como parte da nova concepção dinâmica e orgânica da arquitetura que emerge no século XIX, para a qual, particularmente, a estrutura é o meio capaz de gerar plenamente a unidade orgânica da forma. Nessa perspectiva, demonstrar que o racionalismo estrutural é uma das fontes, e mais precisamente uma das grandes 
fontes da arquitetura moderna brasileira, permite aprofundar o conhecimento tanto dos pressupostos teóricos quanto das qualidades formais dessa arquitetura. Bem como, consequentemente, de questões mais gerais como o método de composição e o papel cultural da arquitetura que interessam hoje e sempre à teoria e à prática da arquitetura.

Palavras-chave: fontes teóricas, arquitetura moderna brasileira, racionalismo estrutural, história cultural da arquitetura.

\begin{abstract}
Resumen
La investigación tiene dos objetivos principales: primero, aumentar el conocimiento de las fuentes de la teoría y la práctica de la arquitectura moderna brasileña y, segundo, contribuir a la consolidación de la historia cultural de la arquitectura en Brasil. Estudiar el racionalismo estructural como fuente de la arquitectura moderna brasileña no solo significa profundizar el conocimiento ya en progreso, sino también aplicar el método de la historia cultural a la historia de la arquitectura en Brasil. La reciente investigación sobre el racionalismo estructural se benefició del método de la historia cultural y es ahora una parte de la nueva historia arquitectónica del siglo XIX, elaborada desde 1990 aproximadamente. En este contexto, la definición exacta del racionalismo estructural está amplificada y profundizada. En lugar de simplemente buscar una relación de causa y efecto entre la estructura y la arquitectura, en el cual la estructura es uno de los fines de la arquitectura, el racionalismo estructural es ahora entendido como parte de una nueva dinámica y orgánica concepción de la arquitectura que emerge en el siglo XIX, en la que, particularmente, la estructura es el medio capaz de generar completamente la unidad orgánica de la forma. En esta perspectiva, demostrar que el racionalismo estructural es una de las fuentes, y más concretamente, una de las más grandes de la arquitectura moderna brasileña, no solo permite profundizar la información de las suposiciones teóricas, sino también las cualidades formales de la arquitectura. Además, como consecuencia, los asuntos más generales como el método de composición y el papel cultural de la arquitectura tan relevantes hoy y como siempre a la teoría y práctica de la arquitectura.
\end{abstract}

Palabras-clave: fuentes teóricas, arquitectura moderna brasileña, racionalismo estructural, historia cultural de la arquitectura.

\section{A matter of method}

$\mathbf{T}$ o postulate structural rationalism as the source of Brazilian modern architecture is not only a matter of sources of research, but also a matter of how the history is made. In this specific case a matter of how Brazilian modern architecture history is made or can be made. ${ }^{1}$

The historiography of Brazilian modern architecture is quite young, as suggested by Abilio Guerra ${ }^{1}$ and is not completely free from prejudices and past simplifications $^{2}$. If this historiography has already made great strides in the last three decades, research can always or must continue to move forward, both to produce new knowledge, and to incorporate new methods and new research objects that contribute precisely to deepen the ongoing historiographical review and therefore to
1 See Abílio Guerra, "A construção de um campo historiográfico", in: Abílio Guerra (Org.), Textos Fundamentais sobre História da Arquitetura Moderna Brasileira, v. 1, São Paulo, Romano Guerra, 2010, pp. 11-22.

2 See Marcelo Puppi, Por uma História Não Moderna da Arquitetura Brasileira, Campinas, Pontes/CPHA -IFCH-Unicamp, 1998 
3 On the current history of the 19 th century, see François Loyer (Org.), L'Architecture, les Sciences et la Culture de l'Histoire au XIXe siècle, Saint-Etienne, Publications de I'Université de Saint-Etienne, 2001; Marcelo Puppi, "A nova história do século XIX e a redescoberta da dimensão imaginária da arquitetura", Arquitextos, n. 058.02, March 2005, http://www.vitruvius.com.br/arquitextos/arq058/arq058_02.asp.

\footnotetext{
4 For the definition of methods and problems of cultural history, see Roger Chartier, Au Bord de la Falaise. L'Histoire entre Certitudes et Inquiétude, Paris, Albin Michel, 1998, and especially the chapter "Le monde comme représentation", pp. 67-86. In general terms, cultural history replaces the social history of culture by the cultural history of social.
}

increasingly overcome prejudices and simplifications of the past. In this context, looking at Brazilian modern architecture from structural rationalism, or more precisely incorporating the history of structural rationalism into the modern Brazilian architecture history can be doubly beneficial.

First, because the latter was inserted methodologically in the context of cultural history, such as the recent research devoted more generally to the history of nineteenth-century architectur ${ }^{3}$, and produced knowledge capable of enhancing the understanding not only of the nineteenth-century architectural theory but also the theory (and practice) of the twentieth century. In the precise sense in which the cultural history of structural rationalism could reveal aspects of twentieth-century architecture that are still little known or even unknown. Second, because the comparative study of one and the other allows to deepen the knowledge of Brazilian modern architecture sources, expanding the research already started and contributing to the discovery of questions that are not yet part of it, by producing new objects and new research problems. Or, in other words, by understanding the idea that the Brazilian modern architecture voluntarily and involuntarily inherited from structural rationalism we can increase what we already know or reveal a new point of view of an already known object or even reveal an architecture different from what we were used to look. As it is the purpose of studying the sources in history.

Briefly, it is not only a matter of the indispensable sources research, but also of applying the method of cultural history to the modern architecture study 4 . An application that is still very rare even at the international level of research in architectural history, which can at least contribute to diversify and enrich research on the Brazilian modern architecture history and which also has the potential to contribute to deepen the knowledge of modern architecture general history.

\section{Definitions}

\section{What is structural rationalism?}

The research development on the sources of Brazilian modern architecture implies the definition of what structural rationalism is. But before presenting what it is, it is indispensable to say what it is not.

First, structural rationalism does not mean subordinating or reducing architecture to structure. At best, 
that is to say, at worst, the equality of terms, or the equality of the principles of structure and form. According to Viollet-le-Duc, structure and form are to be confused forming an inseparable and indistinguishable unity, in the sense that it is not possible in this unit to identify what belongs to one or the other. In the eyes of Viollet-le-Duc, the Gothic structure exemplifies precisely this unity that confuses structure and form by also confounding, one might add, the observer. This is why, again for the French theorist, Gothic architecture must serve as a source of inspiration for contemporary architects (of his time), not by imitation but in its principles. However, to defend that structure and form should be confused does not mean that architecture submits itself to structure. For him, as well as for his archrival Léonce Reynaud, form derives from structure, but that is already another story, for derivation neither establishes nor implies subordination.

Second, and consequently, structural rationalism does not affirm the primacy of technique. Defending the incorporation, or reincorporation of the technique in both the constructed object and the conception process of architecture, does not necessarily nor predominantly mean subordinate the form to the structure. It is, rather, to ascribe a rational foundation to form, hence the name rationalism; but also to ascribe rational foundation to form is one thing, to give primacy to technique is something else. In structural rationalism, the rational foundation of form is a means to insert architecture in the context of the time (the nineteenth century is or was already defined as the century of science _ although it is also more than that) making it again able to interact with the society in which it belongs. The form must be rational so that the architecture becomes dynamic and can exert an active action on the society, an action distinct and higher than the technique and the science. Not to cease to be architecture, that is, to be form. However, this is already what structural rationalism is, not yet what it is not.

Finally, and precisely, structural rationalism does not question the aesthetic nature of architecture, much less opposes it. In order to defend himself against the accusations of medieval sectarianism, Viollet-le-Duc dedicates to valuing indirectly the aesthetic dimension in his Entretiens sur l'architecture in which the Greek temples artistic refinement rivals with the aesthetic-structural prowess of the Gothic cathedrals. At the other extreme, Léonce Reynaud, who graduated as an engineer, and who is not distinguished by the clarity of his writings, explicitly states that art is above science and that, consequently and implicitly, architecture is 
above engineering. For Reynaud, neither architecture is confused with engineering, nor is form confused with structure (as opposed to Viollet-le-Duc). It is never too much to remember that, in addition to being the century of science, the nineteenth century is also the century of romanticism and the rediscovery of the aesthetic dimension, not only on the level of art, but equally and especially on the level of knowledge. A contradictory century in short, for the pleasure of the contradictory spirits such as Reynaud and contemporary architects like Labrouste and Vaudoyer who were his colleagues when he attended the Ecole des Beauxarts in the second decade of the nineteenth century. We can finally get to what structural rationalism is.

In its more general definition, structural rationalism is a new organic and dynamic conception of architecture, which seeks to insert it into the culture of its time and make it capable of interacting with the society to which it belongs. In these terms, the definition of structural rationalism is common to Romantic historicism that is contemporary with and with which, consequently, it has great affinities (it is no coincidence that an architect like Henri Labrouste is considered to be both rationalist and romantic historicist). With the great difference that, in structural rationalism, structure is precisely the means by which architecture can become organic by fully integrating with the culture of the time and by exerting an active action on the public. In the context of the romantic culture from which structural rationalism emerges, structure is conceived as an indivisible organism, in the strictly physical sense of constituting a set of parts that depend on each other and are in a state of equilibrium. In turn, as an organism, the structure is the means by which the architecture, that is, the form can become organic itself. The structure thus constitutes the source of architecture, or precisely the source of the organic unity of architecture. As a source, the structure needs not necessarily to be present, or visible, in the architecture. If, for Viollet-le-Duc, structure and form must remain visible and confused, for Reynaud the form is born from the structure but the structure disappears in the form, remaining only in the vestigial state. This to a lesser or greater extent, as exemplified by the three Greek orders which are organized from the least to the most vestigial and according to the character one wants to attribute to the work. As an engineer who acquired a broad knowledge of the sciences of his time, from exact to biological, Reynaud considered that the scientific or rational unity of structure was incomplete in the sense that, although every structure necessarily constituted an indivisible 
whole, nature structure is rarely visible to the naked eye. For him, only art has the capacity to generate a true organic unity, that is, a complete and visible organic unity, completing but going beyond, and even beyond, the physical-mathematical unity of structure. If the structure is the source of the architecture, this in turn, in his words, is a being that the architect has to imagine and create. Reason why, for Reynaud, art is beyond and above science, just as form is beyond and above structure.

In order to understand structural rationalism, one must therefore first know that it is inserted or derived from the romantic culture of the first half of the nineteenth century, that is, that structural rationalism is a theory (of architecture!) that belongs to the context of the 19th century culture and, second, that the structure is a means, not the goal, much less the end of architecture. If, as we have seen, there are great differences between the two greatest French rationalist theoreticians of the nineteenth century, and if the architect Viollet-le-Duc disapproves of the prerogatives of art defended significantly by the engineer Reynaud, both seek principles or methods capable of making the architecture organic, rather than purely and simply enhance the structure. The simpler definition, or more practical, of structural rationalism as an ornate structure only acquires its full meaning within this context, which was sufficiently evident to contemporaries, but which is no longer absolute in the eyes of a different age and culture.

\section{Which Brazilian Modern Architecture?}

In times of plural architectures, proposing structural rationalism as the source of modern Brazilian architecture, in the singular, asks for a brief explanation. That modern architecture in Brazil encompasses distinct manifestations and a wide variety of forms, is well-known and evident. But it is also known that variety does not exclude unity and that it is precisely one way of enriching unity; or, in the terminology of architecture theory itself, to make it complex and contradictory. This is why architecture, in its great manifestations, has always been characterized both by unity and variety, and, in the most precise and penetrating definition of the nineteenth century, by "unity in the variety" ${ }^{\prime}$. This is precisely why structural rationalism, which simultaneously defended and valued unity and variety and which itself embraces distinct and even opposing principles regarding theory of architecture, can also be defined and named in the singular. The already known and recognized qualities of Brazilian
5 On the principle of the unity in the variety in the culture of the 19th century, see Marcelo Puppi, La Dimension Culturelle du Rationalisme Structurel. Architecture, histoire et utopie chez Léonce Reynaud, Fernand de Dartein et Auguste Choisy, Doctorade Thesis, Paris, Université de Paris 1 Panthéon-Sorbonne, 2013, pp. 91-134. 
modern architecture allow us to state that it is part of the rule, not the exception.

However, in the current historiography of modern architecture in Brazil it goes as if the discovery of plurality excludes unity and, consequently, excludes the search of sources that allow us to understand the reason of unity (among other things, of course). Or as if the rediscovery of plurality undermines unity by identifying it with an outdated view of history. In this sense, current historiography makes the same mistake as the preceding one, replacing (only in the method, not in the quantity of information) the extreme of unity by the opposite extreme of plurality. Or unity, or plurality. But the two extremes suggest that there are both the history of unity and that of plurality in modern architecture in Brazil, regardless of the point of view of one or the other. Neither a history in the singular nor a history in the plural. A history of the singular and the plural all at the same time.

One can even say that, although little recognized, this history of unity and plurality already exists, or has already begun. I refer to the history and chronology of modern Brazilian architecture exposed and proposed by Carlos Eduardo Comas in the set of his seminal and very fine studies on the subject. In general terms, for what matters here, this history comprises a great initial period characterized by unity and a later period that arises from the loss of that unity. From the chronological point of view, the unity corresponds to the period 1930-1960. And from then on, "for better or for worse, unity is lost and is without return"(COMAS, 2002, p. 237); a period which, if I see correctly, can be called plurality. In this one and plural history at the same time, the unity period is rightly named Brazilian modern architecture, in the singular.

This is the modern Brazilian architecture that interests this research, although not exclusively. The aim of this research on structural rationalism as a source of modern Brazilian architecture is not to rewrite its history, but to continue expanding the knowledge on the subject. Or more generally, as stated before, to contribute to the consolidation of the cultural history of architecture in Brazil.

\section{The potential}

\section{Theory}

The identification of the Brazilian modern architecture's theoretical sources and the comparative analy- 
sis of structural rationalism and modern Brazilian architecture's constitutive writings are the most evident contributions of this research. The goal is not to rewrite its history but to continue and expand work already underway, also exemplified by the fundamental studies of Carlos Eduardo Comas. On the other hand, the communications gathered in the session "Structural Rationalism and the sources of Modern Brazilian Architecture: theory, history and imaginary", coordinated by the author in the IV ENANPARQ, are dedicated to verifying from different angles and in different ways the theoretical relations existing between one and the other, and to demonstrate, directly or indirectly, that structural rationalism is in fact one of the great sources of Brazilian modern architecture ${ }^{6}$.

The knowledge of structural rationalism as a new theory of architecture (of the nineteenth century) and the demonstration that it constitutes one of the great sources of the conception of Brazilian modern architecture (and the writings that underlie it) can contribute to further clarify its theory and practice. In the sense in which modern Brazilian architecture proposes or, for the moment, suggests putting into practice the great theoretical principles of structural rationalism, and which part of its best formal qualities derive from that purpose. A hypothesis that, if proven, would also explain the existing unity behind the great diversity of forms, or precisely behind the formal materialization of modern Brazilian architecture. Among many other things, such as the nature at once organic and contradictory, that is, double or ambivalently contradictory of this architecture, from which also emerge its enchantment ${ }^{7}$. As well as the cultural potential that it subtly and implicitly claims, that is, the potential, or function, in the properly organic sense, of exerting an active action on the public's thinking.

\section{History}

The second major contribution of the research concerns the way in which the thought of structural rationalism was transmitted to modern Brazilian architecture. If on the side of structural rationalism there are articles, books, dictionaries and treatises that can be called theoretical writings and which form a theoretical body that is sufficiently vast and complete, on the side of modern Brazilian architecture, there is no such thing as an architecture theory. Except, as we know, some fundamental but rare writings by Lucio Costa, which are evidently based on a well-founded and elaborated thought, but which expose only the main or most urgent arguments of the theoretician.
6 See IV ENANPARQ, Porto Alegre, 25-29 July 2016 [electronic resource]/ Organization: Claudia Costa Cabral, Carlos Eduardo Comas. - Porto Alegre: PROPAR/UFRGS, 2016.

7 On the enchantment of contradiction, see precisely Carlos Eduardo Comas, "O encanto da contradição: Conjunto da Pampulha, de Oscar Niemeyer", Arquitextos, special text 011, September, 2000, http:// www.vitruvius.com.br/arquitextos/ arq000/esp011.asp 
8 On the history as theory of architecture, see Marcelo Puppi, La Dimension Culturelle du Rationalisme Structurel. Architecture, histoire et utopie chez Léonce Reynaud, Fernand de Dartein et Auguste Choisy, op. cit., pp. 386-475; Marcelo Puppi, "Do século XIX ao XX. O papel da história na representação e na prática da arquitetura", 19\&20, v. VII, n. 2, April/June 2012, http:// www.dezenovevinte.net/artedecorativa/mpuppi_representacao.htm.
Even in Lucio Costa, writings of a historical character are more numerous than the few writings of a theoretical nature.

If it can be lamented today that Lucio Costa deprived us of knowing all his thought, how he himself exposed it to us reveals much of how he conceived the role of theory in architecture. For him, the theory was not transmitted exclusively nor mainly through the author's argumentative reason and the pure intelligence of the reader, but in a much more subtle and incisive form of a historical description. Or a narration apparently historical which transmits between the lines a theory which is intended not to convince by reason but to persuade by imagination, an imagination of theoretical nature but which feeds on the deeper foundations of thought, that is, on an imaginary. In other words, Lucio Costa predominantly exposed theory in the form of history (of art, architecture, and civilization), or more precisely, he conceived history as theory of architecture ${ }^{8}$.

The romantic culture of the nineteenth century favoring the transmission of thought in the form of historical narrative, the architects and theorists of nineteenth-century architecture did not hesitate to appropriate it for the diffusion of their architecture theory. In structural rationalism, in particular, the historical narrative has become one of the privileged means for the dissemination of the theory. Even when it came to writings of a theoretical nature, that is, an argument directed to reason, they were accompanied or supplemented by an illustrative or persuasive historical description. This applies to both Viollet-le-Duc and Reynaud, but more to Reynaud than Viollet-le-Duc, to limit ourselves to the examples given above. Not for the sake of Reynaud and his students and disciples Fernand de Dartein and Auguste Choisy the historical narrative is capable of exerting a much more powerful, profound and lasting action on the architects than the theoretical writing. This is because it is able to directly reach the imaginary of the public, transmitting an entire imaginary, rather than just a theory. But this is already the third great contribution that the research intends to give to the study of Brazilian modern architecture.

\section{Imaginary}

The imaginary dimension of architecture is the least obvious but not the least important contribution of this research. For architects of the nineteenth century in general, and for structural rationalism in particular, 
the imaginary dimension is fundamental both for the very definition of architecture and, especially, for its conception process. For Reynaud who embraced romantic culture and Saint-Simonian thought, the being that the architect creates is born of his imagination and speaks directly to the imagination of the public ${ }^{9}$. A creative imagination that derives from an imaginary materializing and transmitting precisely this imaginary. If the imaginary dimension plays a minor role, or is perhaps only less evident in Viollet-le-Duc, it is equally relevant to some of the great representatives of nineteenth-century architecture as Vaudoyer and Labrouste who have much in common with Reynaud.

But it is structural rationalism, or Reynaud in particular, who elevates architecture to the imaginary field by attributing to it the capacity or power to formally represent a new thought, that is, to materialize an intellectual representation, and to invite the public to discover and to appropriate a new representation of reality. He never stated it in the direct and discursive form of architectural theory, but he reveals it indirectly and implicitly in the persuasive form of historical narration and architectural composition ${ }^{10}$. Here again, as stated above, the historical description is the privileged means of teaching architecture theory, for him as for most of his contemporaries. As for the imaginary dimension of composition, Reynaud himself set about experimenting with it in practice in his rare works of architecture which were evidently considered by him to be precisely experimental creations. His best-known project, the Bréhat Lighthouse that he himself values and reproduces in his Traité d'Architecture, can be understood as the formal materialization of a new representation of reality, or as a work of art that feeds on an imaginary for disseminate it by awakening and touching the public's imagination ${ }^{11}$.

In short, for Reynaud and his direct and indirect disciples, architecture not only belongs entirely to the culture level but, above all, it is capable of elevating herself and elevating culture to the highest level of human creation. Like his Bréhat Lighthouse that raises toward the infinite sky raising the spirit and pointing equally to a higher, more complex, more powerful thought and form of social organization.

How can we not recognize that this is one of the sources of Lucio Costa's thought and one of the, if not the great source of the compositions of modern Brazilian architecture? This is what can and should be demonstrated in this singular history. Not only to better understand the source of inspiration for works
9 "[L'architecture] est l'art de projeter et d'élever des édifices destinés non seulement à satisfaire aux besoins physiques des hommes, mais encore à parler à leur imagination" (Léonce Reynaud, "Architecture", Encyclopédie Nouvelle, t. 1, Paris, Librairie de Charles Gosselin, 1836, p. 770).

10

On the imaginary dimension in the history of architecture, see Marcelo Puppi, La Dimension Culturelle du Rationalisme Structurel. Architecture, histoire et utopie chez Léonce Reynaud, Fernand de Dartein et Auguste Choisy, op. cit., pp. 386-475..

11 On the imaginary dimension in the Bréhat Lighthouse, see Marcelo Puppi, "L'imagination des phares chez Léonce Reynaud", Livraisons d'histoire de l'architecture, v. 24, December 2012, pp. 63-83. 
that, several of them, belong to the set of the highest architectural and cultural creations of the twentieth century, but also to continue the work of rediscovering today in Brazil what is and how to make architecture.

\section{Referênces}

CHARTIER, Roger. Au Bord de la Falaise. L'Histoire entre certitudes et inquiétude. Paris: Albin Michel, 1998.

COMAS, Carlos Eduardo. "O encanto da contradição: Conjunto da Pampulha, de Oscar Niemeyer". Arquitextos, texto especial 011, setembro de 2000, http://www.vitruvius. com.br/arquitextos/arq000/esp011.asp.

COMAS, Carlos Eduardo. "Moderna (1930 a 1960)". In: MONTEZUNA, Roberto (Org.). Arquitetura Brasil 500 anos. Recife: Universidade Federal de Pernambuco, 2002, v. 1.

GUERRA, Abílio (Org.). Textos Fundamentais sobre História da Arquitetura Moderna Brasileira. São Paulo: Romano Guerra, 2010, v. 1.

LOYER, François (Org). L'Architecture, les Sciences et la Culture de I'Histoire au XIXe Siècle. Saint-Etienne: Publications de I'Université de Saint-Etienne, 2001.

PUPPI, Marcelo. Por uma História Não Moderna da Arquitetura Brasileira. Campinas: Pontes/CPHA-IFCH-Unicamp, 1998

PUPPI, Marcelo. "A nova história do século XIX e a redescoberta da dimensão imaginária da arquitetura". Arquitextos, n. 058.02, março 2005, http://www.vitruvius.com.br/arquitextos/arq058/arq058_02.asp.

PUPPI, Marcelo. "Do século XIX ao XX. O papel da história na representação e na prática da arquitetura". 19\&20, v. VII, n. 2, abril/junho 2012, http://www.dezenovevinte.net/artedecorativa/mpuppi_representacao.htm.

PUPPI, Marcelo. "L'imagination des phares chez Léonce Reynaud". Livraisons d'histoire de I'architecture, v. 24, dezembro 2012, pp. 63-83.

PUPPI, Marcelo. La Dimension Culturelle du Rationalisme Structurel. Architecture, histoire et utopie chez Léonce Reynaud, Fernand de Dartein et Auguste Choisy. Tese de Doutorado. Paris: Universidade de Paris 1 Panthéon-Sorbonne, 2013. 